\title{
Physico-chemical and phytoplanktonic characteristics of river Tons at Dehradun (Uttarakhand), India
}

\author{
F ouzia Ishaq ${ }^{1 *}$, D.R. K hanna ${ }^{1}$ and A mir K han ${ }^{2}$ \\ ${ }^{1}$ Department of Zoology and Environmental Science, Gurukula Kangri University, Haridwar-249404 (Uttarakhand), INDIA \\ ${ }^{2}$ Glocal School of Life Science, The Glocal University (GU), Ali Akbarpur, Mirzapur Pol, Saharanpur, 247001, (UP) INDIA \\ *Corresponding author. E-mail: fouziaishaq@ gmail.com
}

Received: 0 ctober 5, 2013; Revised received: December 1, 2013; Accepted: D ecember 3, 2013

\begin{abstract}
The physico-chemical and phytoplankton characteristics of the Tons River were analyzed during August 2011-July 2012. The samples were collected from Garhi Cant (Site 1) and Tapkeshwar temple (Site 2) at Dehradun. The results showed that temperature, velocity, DO, nitrate and phosphate affected the phytoplanktonic diversity of river Tons. Thirty five genera of phytoplankton belonging to three families of Chlorophyceae, Bacillariophyceae and Myxophyceae were also identified in the river water. The family Bacillariophyceae was dominating the river with much abundance throughout the study period. Bacillariophyceae was recorded with the maximum of $222.25 \pm 90.84$ Unit/L at sampling site 1 and $239.08 \pm 125.41$ Unit/L at sampling site 2 . The greater number of individuals was in family Bacillariophyceae (239.08 $\pm 125.41 \mathrm{Unit} / \mathrm{L})$ followed by Chlorophyceae (183.75 $\pm 112.50 \mathrm{Unit} / \mathrm{L})$ and Myxophyceae $(40.91 \pm 36.16$ Unit/L) during the study period. Both the number of genera and number of individuals belonging to each genera was maximum in case of family Bacillariophyceae followed by Chlorophyceae and Myxophyceae. The present study revealed that the water quality of river Tons was fairly good for the growth and survival of phytoplankton, and as a result it sustains the higher phytoplankton diversity of Tons river.
\end{abstract}

Keywords: Physico-chemical characteristics, Phytoplankton abundance, Pearson correlation coefficient, River Tons

\section{INTRODUCTION}

Phytoplankton is the primary producer community and consists mainly of algae such as diatoms, dinoflagellates and a variety of forms from other divisions of the plant kingdom. These are very sensitive to the environment they live in and any alteration in the environment leads to the change in their communities in terms of tolerance, abundance, diversity and dominance in the habitat (Amarsinghe and Viverberg, 2002; Elliott et al., 2002). Water maintains an ecological balance between various group of living organism and their environment (Khanna et al., 2012). The physical and chemical characteristics of water bodies affect the species composition, abundance, productivity and physiological conditions of aquatic organisms. These stressed systems support an extraordinarily high proportion of the world's biodiversity. Phytoplankton is one of the most essential characteristics of the aquatic ecosystem for maintaining its stability and a means of coping with any environmental change (Hambright and Zohary, 2000). Therefore, phytoplankton population observation may be used as a reliable tool for biomonitoring studies to assess the pollution status of aquatic bodies. The phytoplankton in a water body is an important biological indicator of the water quality. Phytoplankton studies and monitoring are useful for control of the physico-chemical and biological conditions of the water in any irrigation project. Therefore certain groups of phytoplankton, especially blue green algae, can degrade recreational value of surface water, particularly thick surface scum, which reduces the use of amenities for contact sports, or large concentrations, which cause deoxygenation of the water leading to fish death (Whitton and Patts, 2000).

Over the last few decades, there has been much interest in the processes influencing the development of phytoplankton communities, primarily in relation to physico-chemical factors (Akbay et al., 1999; Peerapornpisal et al., 1999). The algae co-occur even though each species has a specific niche based on its physiological requirements and the constraints of the environment. These are many detailed descriptions of phytoplankton succession being correlated with changes in environmental parameters particularly temperature, light, nutrients availability and mortality factors such as grazing and parasitism (Roelke and Buyukates, 2002). Because the variation of phytoplankton succession is strongly linked to meteorological and water stratification mixing processes, patterns in temperate ecosystems differ considerably from those of tropical waters (Whitton and Patts, 2000). The main objectives of the study were to determine phytoplankton diversity and water quality in 
river Tons and to study the effects of physico-chemical parameters on phytoplankton density.

\section{MATERIALS AND METHODS}

River Tons is the longest and largest tributary of river Ganga arising from two streams (Supin and Rupin rivers) in the Banderpoonch peak of western Himalayas at an elevation of $20,720 \mathrm{ft}(6,315 \mathrm{~m})$ located at $30^{\circ} 29^{\prime} 49^{\prime \prime} \mathrm{N}$ and $77^{\circ} 48^{\prime} 06^{\prime \prime} \mathrm{E}$. The river is one of the perennial Himalayan rivers and a major destination for water-based adventure sports like white-water rafting. The present study was carried out monthly during the year August 2010 to July 2011. Sampling stations namely Garhi cant (Site 1) and Tapkeshwar temple (Site 2) were selected on river Tons in Dehradun Uttarakhand for the collection and analysis of water samples. Physico-chemical parameters viz. temperature, transparency, velocity, conductivity, total dissolved solids (TDS), $\mathrm{pH}$, total alkalinity, total hardness, dissolved oxygen (DO), biochemical oxygen demand (BOD), phosphate and nitrate were analyzed following APHA (1998). For analysis and enumeration of phytoplankton, samples were collected with the help of plankton net of bolting silk no. 25 with a mesh size of 55 $\mu \mathrm{m}$ attached with a collection tube at the base of net. For this a known volume $(10 \mathrm{~L})$ of water was filtered through the planktonic net and sample was collected inside the collection tube. The sample was then transferred in sterilized tubes of $250 \mathrm{ml}$ capacity and preserved in $4 \%$ formaldehyde solution (APHA, 1998; Trivedi and Goel, 1986). The phytoplanktons were made identified following Alfred et al. (1973); Randhawa (1959); Vollenwinds (1969) and Peat (1974). Phytoplankton data was also analyzed by statistical approaches like standard deviation (SD) and Pearson correlation coefficient (r).

\section{RESULTS AND DISCUSSION}

Physico-chemical parameters: The data collected on major water quality parameters is presented in tables 1 and 2. Water temperature is of enormous significance as it regulates various abiotic characteristics and biotic activities of an aquatic ecosystem. In the present study, temperature was recorded maximum of $22^{\circ} \mathrm{C}$ in the month of June both at sampling site 1 (Garhi Cant) and sampling site 2 (Tapkeshwar temple) and minimum of $13{ }^{\circ} \mathrm{C}$ in the month of January at sampling site 2 . The differences in water temperature across the site were significant during different months in river Tons.

Transparency is a characteristic of water that varies with the combined effect of colour and turbidity. In the present study transparency was recorded highest of $18.2 \mathrm{~cm}$ in the month of January at sampling site 1 (Garhi Cant) and lowest $2.5 \mathrm{~cm}$ in the month of August at sampling site 2 (Tapkeshwar temple). Transparency of water in river Tons decreased only during the monsoon seasons. The reason for this was heavy rainfall during monsoon period which brings soil and other sediments resulting in less penetration of light and high productivity coupled with excessive plankton growth. Our results were quite similar with the findings of Amarsinghe and Viverberg (2002).

Velocity was recorded minimum of $0.51 \mathrm{~m} / \mathrm{s}$ in the month of May at sampling site 1 and maximum of $2.56 \mathrm{~m} / \mathrm{s}$ in the month of July at sampling site 2. Velocity is considered as an important spatial character for any river system and play very important role in regulation of the ecology of that particular system (Nautiyal, 1990). Conductivity is a basic index to select the suitability of water for agricultural purposes (Kataria et al., 1995). In the present study the results revealed that conductivity was recorded maximum of $0.477 \mu \mathrm{mho} \mathrm{cm}^{-1}$ in the month of April and minimum of $0.358 \mu \mathrm{mho} \mathrm{cm}^{-1}$ in the month of July at sampling site 1 (Garhi Cant). Conductivity was recorded maximum in summer and monthly variations were significant. Taheruzzaman and Kushari (1995) observed an increase in conductivity in water bodies of Burdwan, West Bengal during monsoon which according to them is due to voluminous runoff carrying diverse types of electrolytes from the nearer as well as distant areas. But according to Sarojini (1996) seasonal fluctuations are closely related to evaporation and concentration of soluble salts.

TDS showed monthly and seasonal fluctuations and were noted most in monsoon period which may be attributed to the heavy rainfall resulting in soil erosion and several fold concentration of elements and minimum in winters due to minimum velocity which favoured effective sedimentation and low level of water causing minimum silt. A change in river water $\mathrm{pH}$ can also affect aquatic life indirectly by altering other aspects of water chemistry e.g. low pH levels can increase the solubility of certain heavy metals. This allows the metals to be more easily absorbed by aquatic organisms. In the present study the $\mathrm{pH}$ of river Tons ranged from the minimum of 8.0 to the maximum of 8.9. The monthly variation in $\mathrm{pH}$ was significant at both the sites throughout the study period. During the entire period of study the $\mathrm{pH}$ of surface water was found mostly alkaline in nature.

Alkalinity of water is its capacity to neutralize a strong acid and is characterized by presence of all hydroxyl ions capable of combining with hydrogen ions (Koshy and Nayar, 2000). In the present study, total alkalinity ranged from minimum of $245.0 \mathrm{mg} / \mathrm{L}$ in the month of August at sampling site 1 to the maximum of $475.0 \mathrm{mg} / \mathrm{L}$ in the month of January at sampling site 2 . Total hardness was recorded highest of $395.0 \mathrm{mg} / \mathrm{L}$ in the month of January at sampling site 2 and lowest of $160.0 \mathrm{mg} / \mathrm{L}$ in the month of August at sampling site 1 . Total hardness was found highest in river Tons during the entire study period. This may be due to presence of salts in the catchment area and may be attributed to presence of high calcium and magnesium 

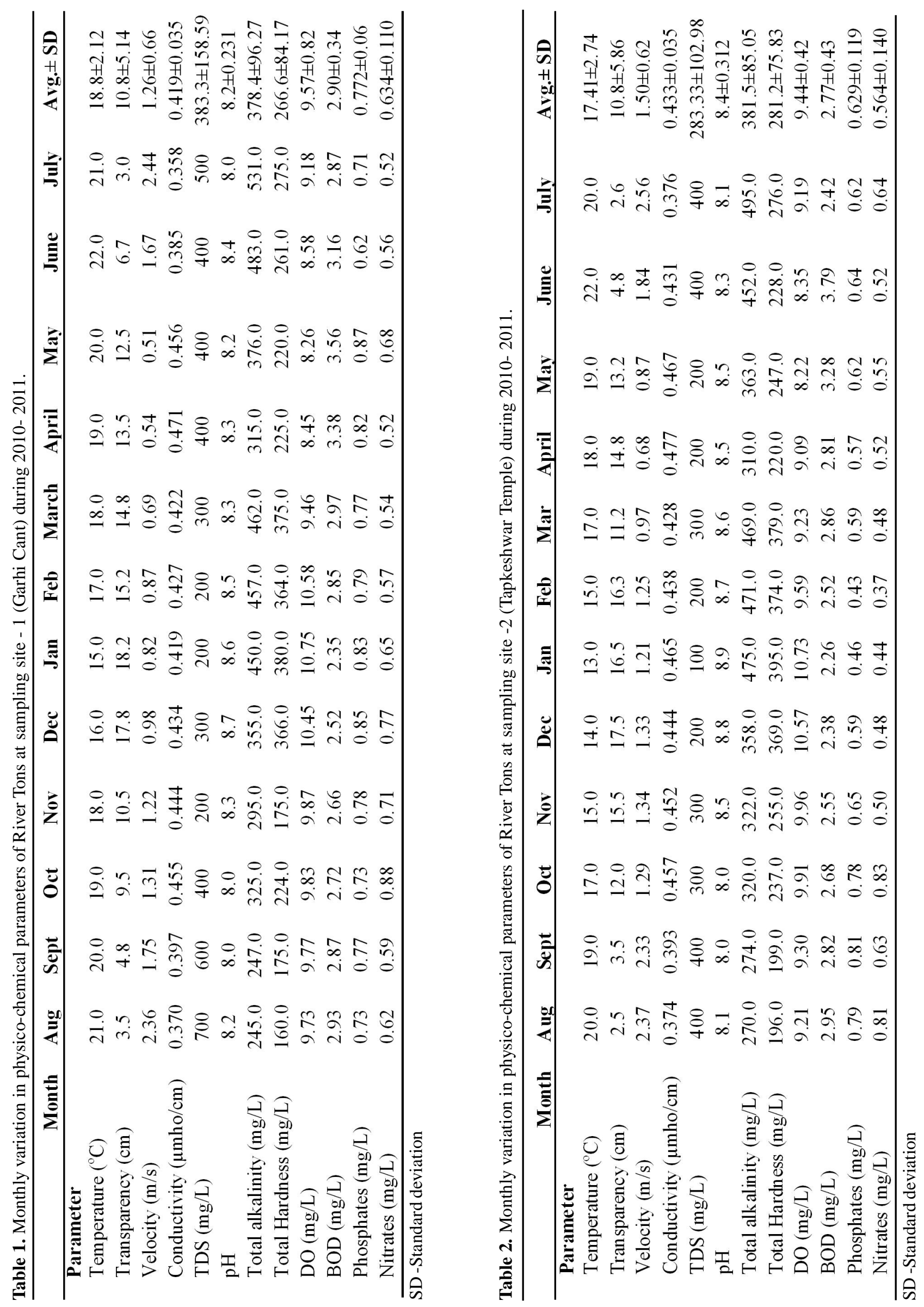


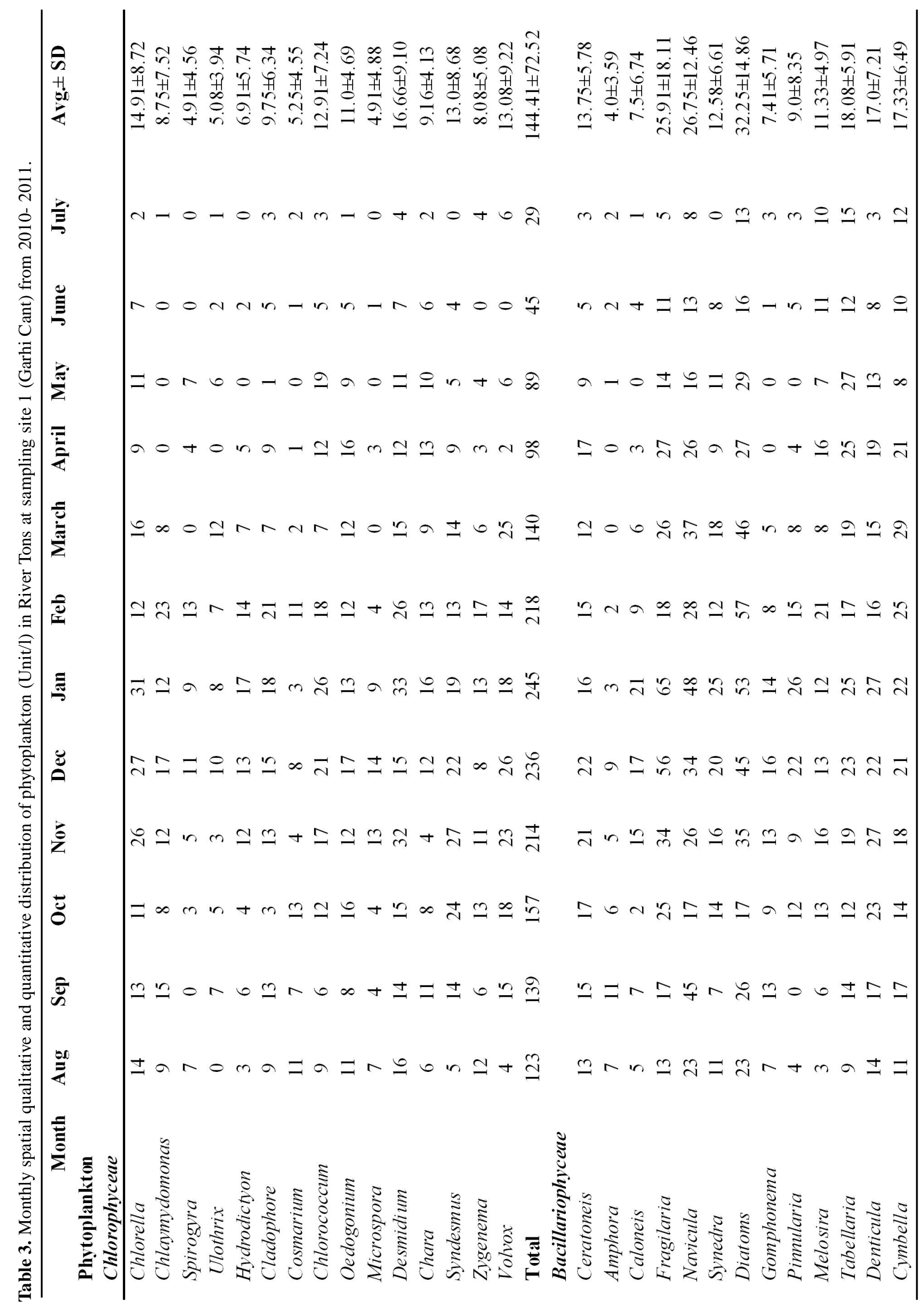




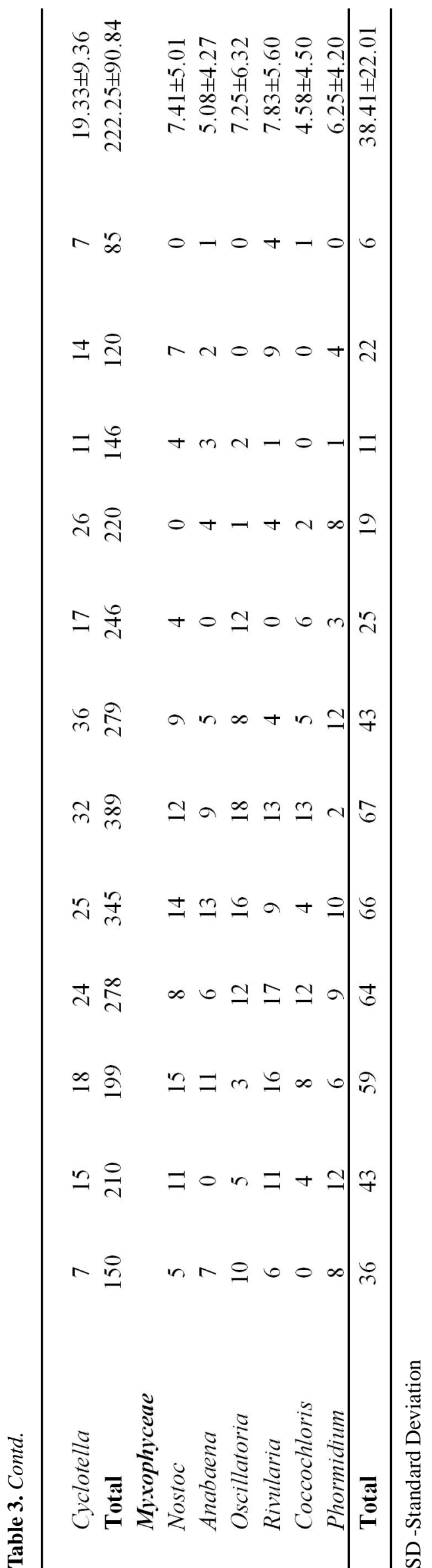

levels. Khanna and Fouzia (2012) observed the similar trend of hardness in River Yamuna.

DO is the sole source of oxygen for all the aerobic aquatic life and hence it is considered as an important measure of purity for all waters. DO reflect the water quality status and physical and biological processes in waters and show the metabolic balance of a river system. DO is an important water quality parameter in assessing water pollution (Laluraj et al., 2002). In the present investigation, DO was found maximum of $10.75 \mathrm{mg} / \mathrm{L}$ in the month of January at sampling site 1 and minimum of $8.22 \mathrm{mg} / \mathrm{L}$ in the month of May at sampling site 2. The monthly values of DO showed a great fluctuations in DO concentration in river Tons. The cause of maximum DO in winter months may be due to the reduced rate of decomposition by decreased microbial activity at low temperature (Prasad and Singh, 2003). Depletion of DO may occur in summer due to increase in temperature as well.

BOD is the amount of oxygen utilized by microorganisms in consuming the organic matter in waters. It is a measure of the actual oxygen demand of wastes under laboratory conditions similar to those found in the receiving waters, and is a good indicator of biodegradability of wastes. BOD increases as the bio-degradable organic content increases in waters. In the present study BOD was recorded with minimum concentration of $2.26 \mathrm{mg} / \mathrm{L}$ in the month of January and maximum of $3.79 \mathrm{mg} / \mathrm{L}$ in the month June at sampling site 2. Jena et al. (2003) reported the same during summer at Sagal Island and Khanna and Singh (2000) noticed peak values during summer in Suswa River of Dehradun. Phosphate and nitrate are considered to be the critical limiting nutrients, causing eutrophication of fresh water systems (Rabalais, 2002). In the present study phosphate and nitrate were present in minimum possible concentration and month variations were quite significant during the study period.

Phytoplankton diver sity and abundance: Phytoplankton is likely to play a key role in solving some environmental problems, in studying photosynthesis, in understanding aquatic ecosystems and in the production of useful substances. In the present study monthly analysis of phytoplankton communities (Tables 3 and 4) as well as diversity and density of different species was carried out to assess the phytoplankton structure of river Tons. The fluctuation in phytoplankton density and abundance was significant during the entire study period. The phytoplankton density and diversity was recorded maximum in winter, moderate in summer and minimum in monsoon period. Khanna et al. (2010) recorded maximum values of phytoplankton in winter and minimum during rainy season. The Phytoplankton diversity inhabitating river Tons comprised of 35 genera out of which Chlorophyceae constitute (15 genera), Bacillariophyceae 


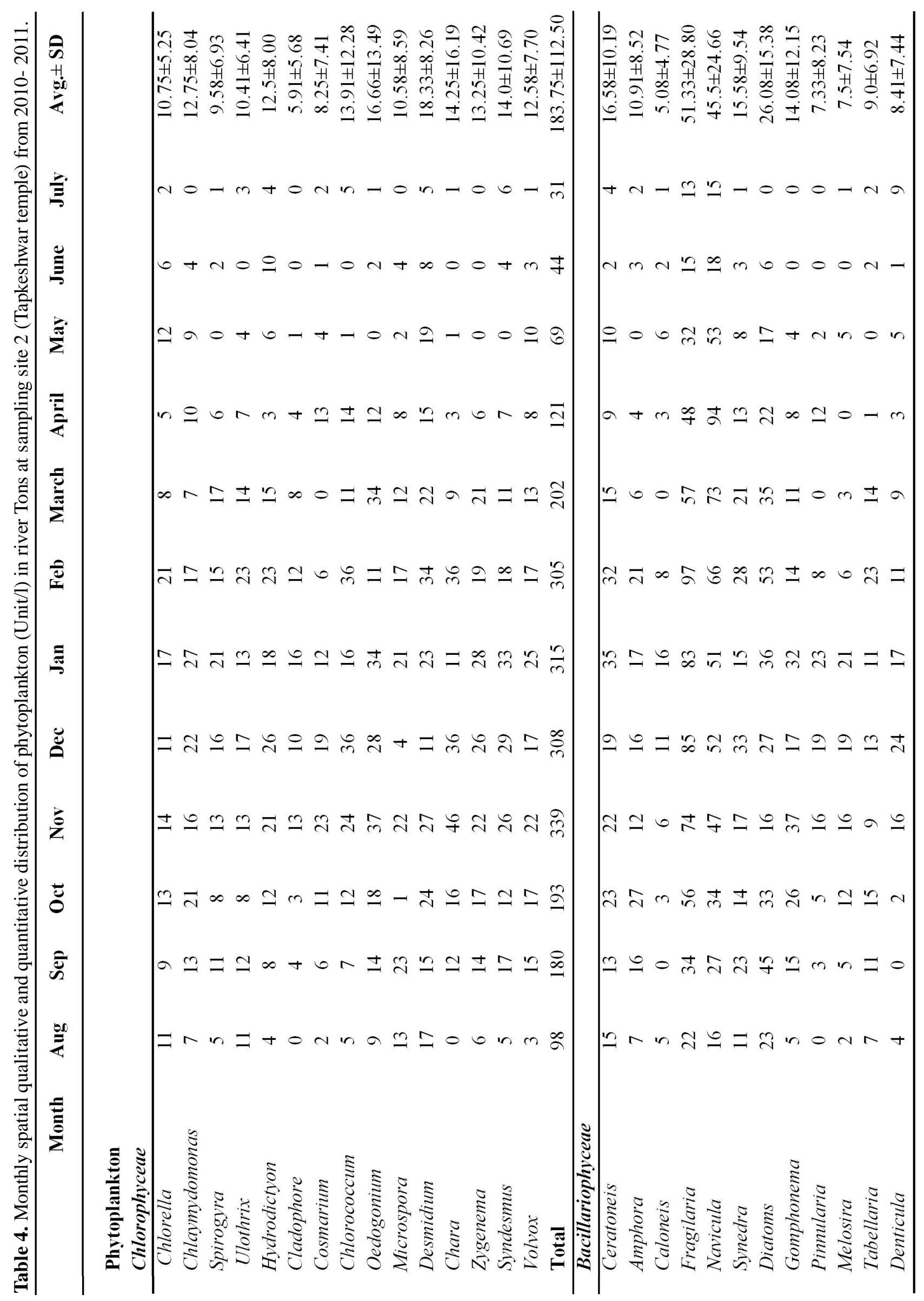



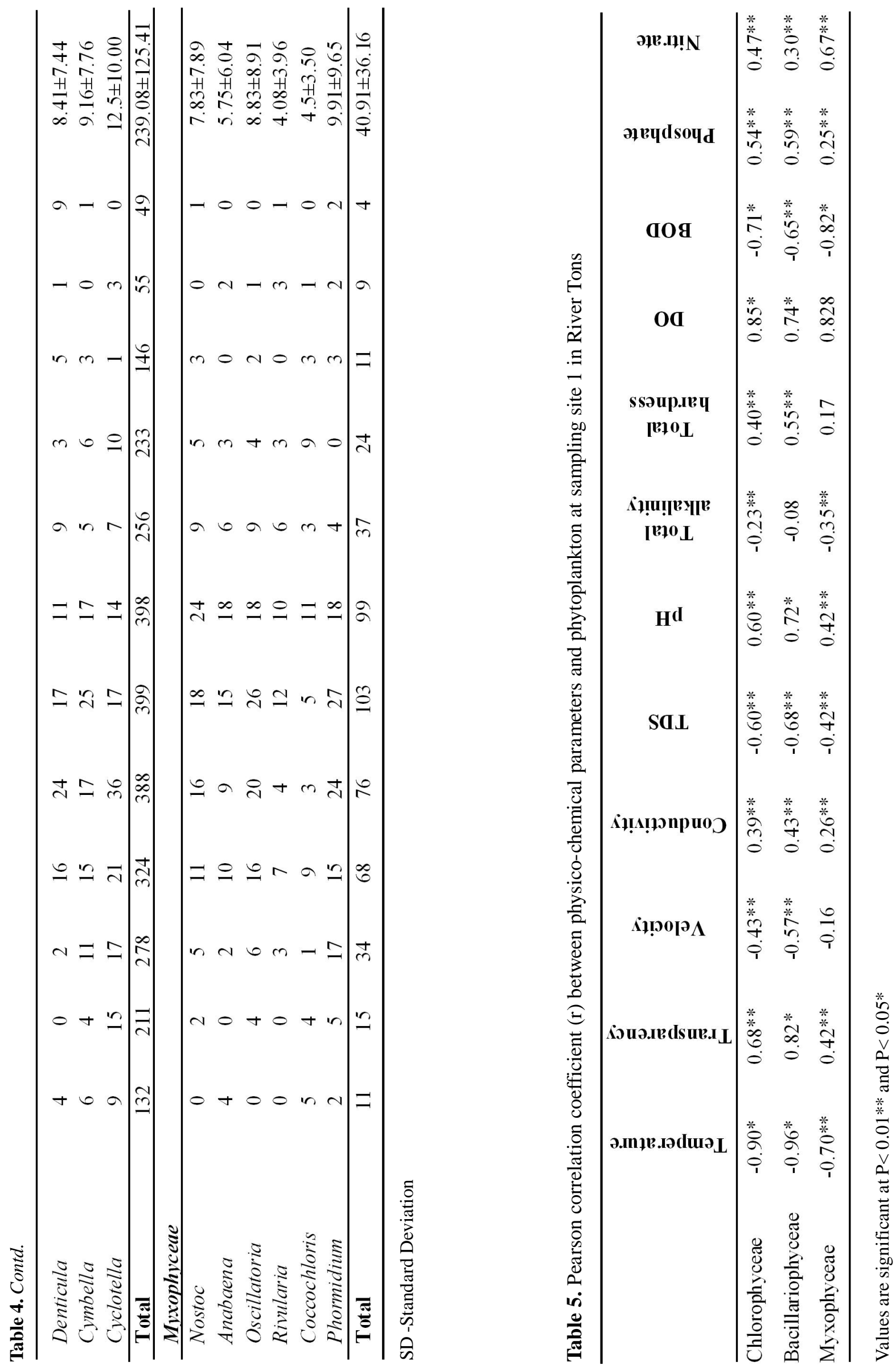
(14 genera) and Myxophyceae (6 genera).

The diversity of Bacillariophyceae biomass was dominating the river Tons. The qualitative study of phytoplankton revealed that the family Chlorophyceae was represented by Chlorella, Chlaymydomonas, Spirogyra, Ulothrix, Hydrodictyon, Cladophora, Cosmarium, C hlorococcum, 0 edogonium, Microspora, Desmidium, Chara, Zygenema, Syndesmus and Volvox. The family Bacillariophyceae was represented by Ceratoneis, Amphora, Caloneis, Fragilaria, Navicula, Synedra, Diatoms, Gomphonema, Pinnularia, M elosira, Tabellaria, D enticula, Cymbella and Cyclotella. The family Myxophyceae was represented by Nostoc, Anabaena, Oscillatoria, Rivularia, Coccochloris and Phormidium. In the present study, the Chlorophyceae was reported maximum of $339 \mathrm{Unit} / \mathrm{L}$ in the month of November at sampling site 2 and minimum of $29 \mathrm{Unit} / \mathrm{L}$ in the month of July at site 1. Bacillariophyceae was reported maximum of 399 Unit/L in the month of January and minimum of 49 Unit/L at sampling site 2 whereas, Myxophyceae was reported maximum of 103 Unit/L in the month of January and minimum of $4 \mathrm{Unit} / \mathrm{L}$ at sampling site 2 (Tables 3 and 4 ).

Nautiyal and Bhatt, (1997) observed the similar trend in River Alaknanda and showed the dominance of phytoplankton. The results also revealed (table 3 and 4) that Desmidium mostly dominate the family Chlorophyceae whereas Fragilaria and Diatoms were dominating the family Bacillariophyceae during the entire study period. The family Myxophyceae was mostly dominated by Rivularia and Phormidium. However, the family that was found with higher diversity was Bacillariophyceae dominating the river and showed much greater abundance among the three families in the river. Hydrological factors such as discharge or water residence time are thought to be of greater importance to planktonic development in rivers (Sileika et al., 2006). It is well known that a combination of physical, chemical and biological factors determine the distribution of the Bacillariophyceae in Rivers (Fabricus et al., 2003).

Diversity of phytoplankton is an indication of purity and the use of community structure to assess pollution is conditioned by four assumptions: the natural community will evolve towards greater species complexity which eventually stabilizes; this process increases the functional complexity of the system; complex communities are more stable than simple communities, and pollution stress simplifies a complex community by eliminating the more sensitive species.

Pearson correlation coefficient $(r)$ between phytoplankton and water quality parameters: Physicochemical factors within all the natural biological systems interact among themselves and with the biotic factors resulting in the formation of a complex relationship which 
is usually called as the environmental complex. Analysis of environmental factors individually is insufficient to trace the exact role of each factor affecting the existence of species population or communities. In such circumstances correlation analysis would be much more fruitful. Correlation analysis between physico-chemical environmental factors and with community characteristics is important to identify certain key relationships crucial to the sustainable management of natural ecosystems. In the present study, the correlation between physicochemical and phytoplankton of river Tons (Tables 5 and 6) revealed that the phytoplankton showed negative correlation with temperature, velocity, TDS and BOD whereas positive significant relation with transparency, conductivity, $\mathrm{pH}$, total hardness and DO. Many reports on positive correlations between density of specific groups of phytoplankton and transparency are available (Unni and Pawar, 2000). Bhade et al. (2001) observed positive correlations of phytoplankton and total hardness of freshwater systems. Correlation studies of phytoplankton and physico-chemical parameters revealed that the relationship between plankton density in general and that of the specific groups are highly complex and often controlled by interactions of different factors, some of which are unidentified. However, certain groups were found to be positively correlated with certain parameter, while certain other groups were found negatively correlated with certain parameters.

\section{Conclusion}

The present study concluded that physico-chemical and phytoplanktonic characteristics of Tons river showed monthly variation. Thirty five genera of phytoplankton belonging to three families of Chlorophyceae, Bacillariophyceae and Myxophyceae were recorded in the river water. The phytoplankton showed positive significant relation with transparency, conductivity, $\mathrm{pH}$, total hardness and DO. The high value of phytoplankton diversity at both the sites indicates good physicochemical conditions of river. Thus the water quality of river Tons was fairly good for the growth and survival of phytoplankton.

\section{ACKNOW LEDGEMENT}

The author's express sincere thanks to Department of Science and Technology (DST), Ministry of Science and Technology New Delhi for the financial support in the form of major research project under Women Scientist Scheme (WOS- A) to Fouzia Ishaq (Principal Investigator) bearing file no. (SR/ WOS-A/LS-170/2010).

\section{REFERENCES}

Akbay, N., Anul, N., Yerti, S., Soyupak, S. and Yurteri, C. (1999). Seasonal distribution of large phytoplankton in Keban dam reservoir. Plank. Res., 21(4): 771-787.
Alfred, J.R.B., Bricice, S., Issac, M.L., Michael, R.G. Rajendran, M., Royan, J.P., Sumitra, V. and Wycliffe, J. (1973). A guide to the study of freshwater organisms. J. Madras. Univ. Suppl., 1: 103-151.

Amarsinghe, B. P. and Viverberg, J. (2002). Primary production in a tropical reservoir in SriLanka. H ydrobiologia, 487: 85-93.

APHA (1998). Standard methods for the examination of water and waste water, $20^{\text {th }}$ ed., Washington D.C. New York.

Bhade, C., Unni, K. S. and Bhade, S. (2001). Limnology and Eutrophication of Tawa Reservoir, M.P. State, India, Verh. Internat. Verein. Limnol., 27:3632-3635.

Elliott, J.A., Irish, A.E. and Reynolds, C.S. (2002). Predicting the spatial dominance of phytoplankton in light limited and incompletely mixed eutro phic water column using the PROTECH model. Fresh. Bio., 47: 433-440.

Fabricus, D. M. A., Maidana, N., Gomez, N. and Sabater, S. (2003). Distribution patterns of benthic diatoms in a Pampean River exposed to seasonal floods: the Cuarto River (Argentina). Biodiversity and Conservation, 12: 2443-2454.

Hambright, K.D. and Zohary, T. (2000). Phytoplankton species diversity control through competitive Exclusion and physical disturbances. Limnol. O ceanogr., 45(1): 110-122.

Jena, B., Sudarshana, R. and Chaudhary, S.B. (2003). Studies on water quality parameters around Sagar Island, Sunderbans.J .Nat.env.and Poll.Tech., 2(3):329-332.

Kataria, H. C., Iqbal, S. A. and Sandilya, A. K. (1995). Limnochemical studies of Tawa Reservoir. Indian J . of Envtl. Prtcn. 16 (11): 841-846.

Khanna, D.R. and Fouzia Ishaq (2012). Analysis of Heavy Metals and their interrelationship with some water quality parameters of River Yamuna in Dehradun Uttarakhand. Biochem. Cell. Arch., 12(2): 273-280.

Khanna, D.R. and Singh, R.K. (2000). Seasonal fluctuations in the plankton of Suswa River at Raiwala (Dehradun). Env. Cons. J ., 1(2\&3):89-92.

Khanna, D.R., Bhutiani, R., Gagan Matta, Singh, V., Tyagi, P., Tyagi, B. and Fouzia Ishaq (2010). Water quality characteristics of River Tons at District-Dehradun, Uttarakhand (India). Env. Cons. J ., 11(1-2): 119-123.

Khanna, D.R., Bhutiani, R., Gagan Matta, Vikas Singh and Fouzia Ishaq (2012). Seasonal variation in physico-chemical characteristic status of River Yamuna in Doon valley. Env. Cons. J ., 13(1\&2): 125-128.

Koshy, M. and Nayar, T. V. (1999). Water quality aspects of River pamba. Pollut. Res., 18(4): 501-510.

Laluraj, C. M., Padma, P., Sujatha, C. H., Nair, S. M., Kumar, N. C. and Chacko, J. (2002). Base-line studies on the chemical constitutes of Kayamkulam Estuary near to the newly commissioned NTPC power station. Indian J ournal of Environmental Protection, 22 (7): 721-731.

Nautiyal, P. (1990). Ecology of the Ganga river system in the upland of Garhwal Himalaya. Environment Resource and Development, 69-73.

Nautiyal, P. and Bhatt, J. P. (1997). Altitudinal variation in phytobenthos density and its component in the cold water mountain river Alakanda- Ganga. Phykos, 36: 81-88.

Peat, R.K. (1974). The measurement of species diversity. Ann. Rev. E col. Systematic., 5: 285-307.

Peerapornpisal, Y., Sonthichai, W., Somdee, T., Mulsin, P. and Rott, E. (1999). Water quality and phytoplankton in the 
Mae Kuang Udomtara Reservoir, Chiang Mai, Thailand. J. Sci. Fac. Cmu., 26(1): 25-43.

Prasad, B.B. and Singh, R.B. (2003). Composition, abundance and distribution of phytoplankton and zoobenthos in a tropical water body. Nat. Envin. Pollut. Technol., 2: 255-258.

Rabalais, N. (2002). Nitrogen in Aquatic system. Ambio., 31(2):102-112.

Randhawa, M. S. (1959). Zygnemaceae . Indian council of Agriculture Research New Delhi 471.

Roelke, D. and Buyukates, Y. (2002). Dynamics phytoplankton succession coupled to species diversity as a system level tool for study of Microcystis population dynamics in eutrophic lakes. Limnol. 0 ceanogr., 47(4): 1109-1118.

Sarojini, Y. (1996). Physico-chemical characteristics and phytoplankton assemblages of sewage entering harbour water at Visakapatanam, East Coast of India. Indian J. of Environmental Protection, 16 (9): 645-650.

Sileika, A., Lnacke, P., Kutra, S., Gaigals, K. and Berankiene,
L. (2006). Temporal and spatial variation of nutrient levels in the Nemunas River (Lithuania and Belarus). Environ. M onit. Assess., 122: 335-354.

Taheruzzaman, Q. and Kushari, D. P. (1995). Study of some physico-chemical properties of the different water bodies in Burdwan with special reference to effluents resulting from anthropogenic activities. I.J.E.P., 15 (5): 344-349.

Trivedi, R.K. and Goel, P.K. (1986). Chemical and Biological method for water pollution studies. Karad Environmental Publications, 1-251.

Unni, K. S. and Pawar, S. (2000). The phytoplankton along a pollution gradient in the river Mahanadi (M. P. State) Indiaa multivariable approach. Hydrobiologia, 430: 87-96.

Vollenwinds, R.A. (1969). A manual on methods for measuring Planktonic composition in aquatic environment. In: IBP Hand Book No-12, UK: Blackwell Scientific Publication, P. 22.

Whitton, B.A. and Patts, M. (2000). The Ecology of Cyanobacteria. Kluwer Academic Publishers, Netherlands. 